\title{
An assessment of the small hydro potential of Opeki River, southwestern Nigeria
}

\author{
Dele Innocent Shobayo ${ }^{1}$, Isaiah Adediji Adejumobi ${ }^{1}$, Olufriopo Samson Awokola ${ }^{2}$, \\ Adio Taofiki Akinwale ${ }^{3}$ \\ ${ }^{1}$ Department of Electrical and Electronics Engineering, Federal University of Agriculture, Abeokuta, Ogun State, Nigeria \\ ${ }^{2}$ Department of Civil Engineering, Federal University of Agriculture, Abeokuta, Ogun State, Nigeria \\ ${ }^{3}$ Department of Computer Science, Federal University of Agriculture, Abeokuta, Ogun State, Nigeria
}

\section{Email address:}

deleshobayo@gmail.com (D. I. Shobayo), engradejumobi@yahoo.com (I. A. Adejumobi), osawokola@yahoo.co.uk (O. S. Awokola), aatakinwale@yahoo.com (A. T. Akinwale)

\section{To cite this article:}

Dele Innocent Shobayo, Isaiah Adediji Adejumobi, Olufriopo Samson Awokola, Adio Taofiki Akinwale. An Assessment of the Small Hydro Potential of Opeki River, Southwestern Nigeria. Science Journal of Energy Engineering. Vol. 2, No. 3, 2014, pp. 25-31.

doi: 10.11648/j.sjee.20140203.12

\begin{abstract}
Nigeria faces an acute shortage of electricity supply and large rural populations have no access to electricity. In this work, the small hydro potential of Opeki River in southwestern Nigeria was assessed. Mean daily flow records for seven years were used to establish a flow duration curve (FDC) for the river and a medium range of heads was evaluated. Conventional power equations were adopted and modified to determine rated output $\left(\mathrm{P}_{\mathrm{k}}\right)$, annual optimal operation period $\left(\mathrm{T}_{\mathrm{o}}\right)$ and to derive power duration curve (PDC) for a proposed plant at the site of interest. The plant's annual energy production $\left(\mathrm{E}_{\mathrm{k}}\right)$ and capacity factor $(\mathrm{C})$ were projected from the PDC. At a net head of $46.5 \mathrm{~m}$, an assessment at average potential power $\left(\mathrm{P}_{\text {ave }}\right)$ with a single Kaplan turbine obtained values of $\mathrm{P}_{\mathrm{k}}, \mathrm{T}_{\mathrm{o}}, \mathrm{E}_{\mathrm{k}}$ and $\mathrm{C}$ as $8.8 \mathrm{MW}, 148$ days, 50,018 MWh, and $65.1 \%$ respectively. Assessment results showed that small hydro electric power generation from Opeki River would improve electricity supply to nearby, off - grid rural communities.
\end{abstract}

Keywords: Hydraulic Turbines, Opeki River, Small Hydro Power

\section{Introduction}

Sub - Saharan Africa (SSA) has an average electricity access level of $14 \%$ as compared to $98.4 \%$ in North Africa, $60 \%$ in South Asia, $74 \%$ in Latin America and $72 \%$ in the Middle East [1]. Most countries in Sub - Saharan Africa, including Nigeria, face an acute shortage of rural electricity. Nigeria's rural electricity access level is $28 \%$ [2]. Rural electrification in Nigeria has been mainly carried out through grid extension [3]. Rural electrification through grid extension is technically challenging and very expensive due to the remoteness and sparseness of rural communities and the cost of maintaining long distribution feeders [4]. As a consequence, rural electrification in Nigeria has been notoriously slow $[3,5]$. The technically exploitable small hydro potential of Nigeria is high but underutilized $[5,6]$. Approximately two - thirds of Nigeria lies in the watershed of the Niger River and Benue River and their tributaries [6]. Several rivers of the watershed; including Cross River (southeastern Nigeria) and the Ogun, Osun and Oyan Rivers (southwestern Nigeria) flow directly southwards into the Atlantic Ocean [6]. Because many off - grid, rural communities in Nigeria are in the proximity of streams and rivers; small hydro power has the capacity to increase electricity access levels of these communities. In spite of the aforementioned; numerous impediments have limited the development of small hydro including the unavailability of relevant data and the lack of a comprehensive national inventory of potential small hydro sites [3], [5]. Therefore, in this paper; an assessment of the small hydro potential of Opeki River, a tributary of Ogun River [7], was carried out.

The definition of a small hydro project varies from one region to another, but a generating capacity not exceeding 10 MW is generally accepted as the upper limit of what can be termed as a small hydro plant in Nigeria [3, 6]. Small hydro electricity generation is marginal from an economic 
viewpoint; hence, a large dam usually renders the project economically unattractive $[8,9]$. Since, most small hydro power plants are run of river developments with no significant water storage facility; the negative environmental impacts including ecological disruption; flooding and social conflicts associated with large scale hydro projects are drastically minimized [9]. In contrast, with the absence of a significant water storage facility; a small hydro plant's power output fluctuates with the hydrological cycle of the river $[9,10]$. Therefore, a reliable assessment of available small hydro resource cannot be achieved without an evaluation of the hydraulic turbine's response to the annual variability of river flow. These evaluations define the energy available at a site of interest. The extensive methods of these evaluations necessitated the development and implementation of the algorithm in this work using Visual Basic programming language.

\section{Equations and Formulations}

\subsection{Measuring Head}

Head in a run of the river small hydro plant is relatively constant. It is defined by the loss of elevation by the river over its stretch between the water surface at the proposed intake and the river level at the point where the water will be returned [9, 11]. The gross head is estimated by on-site measurements or from topographical maps. In this work, head measurements were carried out using both methods. The actual head seen by a turbine, termed the net head, will be slightly less than the gross head due to losses incurred when transferring the water into and away from the turbine via water conveyance structures. The net head was calculated using (1) $[9,10]$.

$$
\mathrm{H}_{\mathrm{n}}=\mathrm{H}_{\mathrm{g}}-\left\{\zeta_{\mathrm{h}}\left(\mathrm{H}_{\mathrm{g}}\right)+\mathrm{h}_{\mathrm{w}}\right\}
$$

where,

$$
\begin{aligned}
& \mathrm{H}_{\mathrm{n}}=\text { net head }(\mathrm{m}) \\
& \mathrm{H}_{\mathrm{g}}=\text { gross head }(\mathrm{m}) \\
& \zeta_{\mathrm{h}}=\text { conduit head percentage loss (typically } 3 \%-8 \% \text { ) } \\
& \mathrm{h}_{\mathrm{w}}=\text { maximum tail water level }(\mathrm{m})
\end{aligned}
$$

\subsection{Modeling Stream Flow}

Having established the site as topographically suitable for small hydro power development, a firm knowledge of the river's flow regime, as depicted by a flow duration curve (FDC), is required. The FDC is a curve with probability of exceedance $(\%)$ on the $\mathrm{x}$ - axis and flow rate $\left(\mathrm{m}^{3} / \mathrm{s}\right)$ on the $\mathrm{y}-$ axis $[8,12]$. The FDC depicts the annual variability of flow in a river and was used to verify the availability of adequate water supply for power generation [12, 13]. An approximation of the area of the region under the FDC provided the average yield of the stream, hence the average flow rate $\left(\mathrm{Q}_{\text {ave }}\right)$ for the multi - year period [13, 14]. Development of the flow duration curve from daily flow records was achieved using a spreadsheet computer application.

Let $\mathrm{Q}_{\mathrm{i}}$ represent the flow values constituting the primary flow duration curve; then, a minimum non-usable flow must bypass the small hydro plant in order to meet environmental regulations and irrigation requirements downstream and to account for leakages that may occur at the point of diversion $[11,12]$. This minimum flow, also known as the residual flow $\left(Q_{r}\right)$, was subtracted from all values of primary flow. Hence, the residual flow effectively shifted the primary FDC downwards thereby reducing the volume of flow available to the turbine and creating a secondary FDC consisting of the flows available for power generation $\left(\mathrm{Q}_{\mathrm{j}}\right)$. The available flow values were thus calculated using $(2)[8,9]$.

$$
Q_{j}=Q_{i}-Q_{r}
$$

$$
\mathrm{i}, \mathrm{j}=\{0,1,2,3, \ldots, \mathrm{n}\}
$$

$\mathrm{n}=$ number of equally spaced intervals on the FDC where,

$\mathrm{Q}_{\mathrm{i}}=$ flow values of the primary $\mathrm{FDC}\left(\mathrm{m}^{3} / \mathrm{s}\right)$

$\mathrm{Q}_{\mathrm{j}}=$ flow values of the secondary FDC $\left(\mathrm{m}^{3} / \mathrm{s}\right)$

$\mathrm{Q}_{\mathrm{r}}=$ residual flow $\left(\mathrm{m}^{3} / \mathrm{s}\right)$

" $\mathrm{i}$ " and " $\mathrm{j}$ " are subscripts indicating the exceedance probability of a flow value on the primary FDC and secondary FDC respectively.

\subsection{Power Output of a Turbine}

In hydro power plants, the energy of flowing water is converted to torque by the turbine. This torque drives the shaft of the turbine which in turn rotates the alternator to produce electricity [14]. The power at the disposition of the turbine is conventionally calculated using the power equation in $(3)[8,14]$.

$$
P=\rho g Q H_{n} \eta_{o}
$$

where,

$$
\begin{aligned}
& \rho=\text { density of water }\left(1,000 \mathrm{~kg} / \mathrm{m}^{3}\right) \\
& \mathrm{g}=\text { acceleration due to gravity }\left(9.8 \mathrm{~m} / \mathrm{s}^{2}\right) \\
& Q=\text { flow rate }\left(\mathrm{m}^{3} / \mathrm{s}\right) \\
& \mathrm{H}_{\mathrm{n}}=\text { net head }(\mathrm{m}) \\
& \eta_{\mathrm{o}}=\text { overall efficiency of the system }
\end{aligned}
$$

\subsubsection{Establishing the Power Duration Curve}

When (3) is expanded to accommodate the distinct efficiencies and losses of the small hydro system and $\mathrm{Q}_{\mathrm{k}}$ is taken as the plant's rated flow; $P_{k(j)}$ is the power output of the small hydro plant due to available flows $\left(Q_{j}\right)$ relative to the plant's rated flow $\left(Q_{k}\right)$ and $P_{k}(j)$ was evaluated using (4) [10].

$$
\begin{gathered}
P_{k(j)}=\rho g Q_{j}\left\{H_{g}-\left(H_{h}+H_{w}\right)\right\} \\
\eta_{t k(j)} \eta_{g}\left(1-\zeta_{t}\right)\left(1-\zeta_{p}\right)
\end{gathered}
$$

$$
\mathrm{j}, \mathrm{k}=\{0,1,2,3, \ldots, \mathrm{n}\}
$$

$\mathrm{n}=$ number of equally spaced intervals on the FDC

$$
\mathrm{Q}_{\mathrm{j}}=\min \left(\mathrm{Q}_{\mathrm{j}}, \mathrm{Q}_{\mathrm{k}}\right)
$$

"j" and " $\mathrm{k}$ " are subscripts indicating the exceedance probability of a flow value on the secondary FDC 
When $\mathrm{Q}_{\mathrm{j}}=\mathrm{Q}_{\mathrm{k}} ; \mathrm{P}_{\mathrm{k}(\mathrm{j})}$ is the plant's rated output $\left(\mathrm{P}_{\mathrm{k}}\right)$. where;

$\eta_{\mathrm{t}}=$ turbine relative efficiency obtained from Fig. 1

$\eta_{\mathrm{g}}=$ generator efficiency (typically $93-98 \%$ )

$\zeta_{\mathrm{t}}=$ transformer losses (typically $1-3 \%$ )

$\zeta_{\mathrm{p}}=$ parasitic electricity losses (typically $1-4 \%$ )

$\rho=$ density of water $\left(1,000 \mathrm{~kg} / \mathrm{m}^{3}\right)$

$\mathrm{g}=$ acceleration due to gravity $\left(9.8 \mathrm{~m} / \mathrm{s}^{2}\right)$

$\mathrm{Q}_{\mathrm{j}}=$ available flows for power generation $\left(\mathrm{m}^{3} / \mathrm{s}\right)$

$\mathrm{Q}_{\mathrm{k}}=$ plant's rated flow $\left(\mathrm{m}^{3} / \mathrm{s}\right)$

$\mathrm{H}_{\mathrm{g}}=\operatorname{gross}$ head $(\mathrm{m})$

$\mathrm{H}_{\mathrm{h}}=$ hydraulic head losses (adjusted over the range of available flows)

$$
\mathrm{H}_{\mathrm{h}}=\mathrm{H}_{\mathrm{g}} \zeta_{\mathrm{h}}\left\{\mathrm{Q}_{\mathrm{j}}^{2} / \mathrm{Q}_{\mathrm{k}}^{2}\right\}
$$

where,

$\zeta_{\mathrm{h}}=$ conduit head percentage loss (typically $3-8 \%$ )

$\mathrm{H}_{\mathrm{w}}=$ tail water head losses (adjusted over the range of available flows) and is defined only for $\left(Q_{j}>Q_{k}\right)$

$$
\mathrm{H}_{\mathrm{w}}=\mathrm{h}_{\mathrm{w}}\left\{\left(\mathrm{Q}_{\mathrm{j}}-\mathrm{Q}_{\mathrm{k}}\right)^{2} /\left(\mathrm{Q}_{\max }-\mathrm{Q}_{\mathrm{k}}\right)^{2}\right\}
$$

where,

$\mathrm{h}_{\mathrm{w}}=$ maximum tail water level $(\mathrm{m})$

$\mathrm{Q}_{\max }=$ maximum river flow from the primary $\mathrm{FDC}\left(\mathrm{m}^{3} / \mathrm{s}\right)$

The power outputs obtained from (4) were used to establish power duration curve (PDC) for the proposed small hydro plant.

The minimum potential power, $\mathrm{P}_{\min }$, is the plant's rated output when minimum annual flow rate is taken as the plant's rated flow [4].

The average potential power, $\mathrm{P}_{\mathrm{ave}}$, is the plant's rated output when average annual flow rate is taken as the plant's rated flow [4].

\subsection{Calculating Turbine Relative Efficiency}

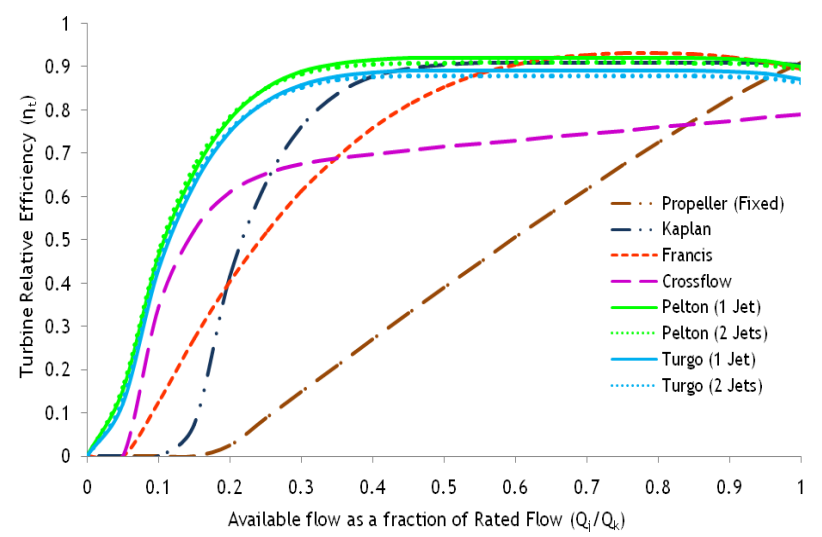

Figure 1. Hydraulic Turbines' Efficiency Curves

The relative efficiency of a hydraulic turbine describes the turbine's efficiency not only at its design flow but also its efficiency at reduced flows (part - flow efficiency) [9, 11]. Even though efficiency guarantees are usually provided by turbines' manufacturers; extensive studies of Kaplan,
Propeller, Francis, Crossflow, Pelton and Turgo turbines have established formulae for calculating these turbines relative efficiencies under varying heads and flows $[10,11]$. These formulae, described in detail in [10], were used to derive efficiency curves for the various turbines considered in this work. These efficiency curves are shown in Fig. 1.

\subsection{Calculating Annual Optimum Operation Period}

The plant's annual optimum operation period is an estimation of the number of days in a year that the small hydro plant can deliver rated output. The annual optimum operation period was calculated using (7).

$$
\mathrm{T}_{\mathrm{o}}=\operatorname{Pr}\left(\mathrm{Q}_{\mathrm{k}}\right) \times \mathrm{t}_{\mathrm{d}}
$$

where,

$\mathrm{T}_{\mathrm{o}}=$ optimum operation period (number of days)

$t_{d}=$ approximate number of days in a year (365 days) (\%)

$\operatorname{Pr}\left(\mathrm{Q}_{\mathrm{k}}\right)=$ exceedance probability of the plant's rated flow

\subsection{Calculating Annual Maximum Reduction in Rated Output}

The annual maximum reduction in the plant's rated output gives an indication of the quantity of power required to complement the small hydro plant during periods of reduced flows. The maximum reduction in the plant's rated output was calculated from the PDC using (8);

$$
\mathrm{P}_{\mathrm{r}}=\mathrm{P}_{\mathrm{k}}-\mathrm{P}_{\mathrm{f}}
$$

where,

$\mathrm{P}_{\mathrm{r}}=$ annual maximum reduction in rated output $(\mathrm{kW})$

$\mathrm{P}_{\mathrm{f}}=$ plant's firm output $(\mathrm{kW})$

The small hydro plant's firm output $\left(\mathrm{P}_{\mathrm{f}}\right)$ is the power output that a small hydro plant can reliably provide throughout the year and is calculated from (4) when $\mathrm{j}=100$ i.e. $\mathrm{Q}_{\mathrm{j}}=\mathrm{Q}_{100}$.

\subsection{Estimating Annual Energy Production}

The annual energy produced by the small hydro plant was calculated by approximating the area of the region under the PDC. To achieve this trapezoidal integration was employed. In order to numerically implement the trapezoidal rule, a domain discretized into " $n$ " equally spaced intervals such that " $n$ " represents the percentage exceedance intervals on the power duration curve with " $n+1$ " flow values was considered. The approximation of the integral is given in (9) $[11,15]$

$$
\int_{a}^{b} f(x) d x=\frac{h}{2} \sum_{z=0}^{n} \quad\left\{f\left(x_{z}\right)+f\left(x_{z+1}\right)\right\}
$$

Equation (9) was modified to calculate the small hydro plant's annual energy production using (10);

$$
\mathrm{E}=\frac{\mathrm{h}}{2} \sum_{\mathrm{j}=0}^{\mathrm{n}}\left\{\mathrm{P}_{\mathrm{k}_{(\mathrm{j})}}+\mathrm{P}_{\mathrm{k}_{(\mathrm{j}+1)}}\right\} \mathrm{t}_{\mathrm{y}} \mathrm{A}
$$


where,

$\mathrm{E}=$ the annual energy produced by the plant $(\mathrm{kWh})$

$P_{k(j)}=$ the power outputs from $(4)(\mathrm{kW})$

A = plant's annual availability (typically $85-98 \%$ )

$\mathrm{t}_{\mathrm{y}}=$ approximated number of hours in a year $(8760 \mathrm{hrs})$

$\mathrm{h}=$ percentage spacing of the intervals on the PDC (1\%)

\subsection{Calculating Annual Capacity Factor}

The small hydro plant's capacity factor is a ratio of the plant's actual energy output over a period of time and its potential energy output if it had operated at rated output the entire time. The plant's annual capacity factor was calculated using (11) [9];

$$
\mathrm{C}=\mathrm{E} /\left(\mathrm{P}_{\mathrm{k}} \mathrm{t}_{\mathrm{y}}\right)
$$

where,

$$
\begin{aligned}
& \mathrm{C}=\text { plant capacity factor } \\
& \mathrm{E}=\text { annual projected energy production from (10) }
\end{aligned}
$$

\subsection{Turbine Application Range Charts}

Charts have been developed to aid the selection of suitable turbines for varying site conditions of flow and head. Typical turbine application range charts are shown in Fig. 2 and Fig. 3. Suitable turbines are those for which a given net head and rated flow plot within the operational envelopes. Although some variation exists between envelopes of the same turbine for charts produced by different manufacturers; these charts serve as an important guide during the prefeasibility stage of small hydro assessment [11].

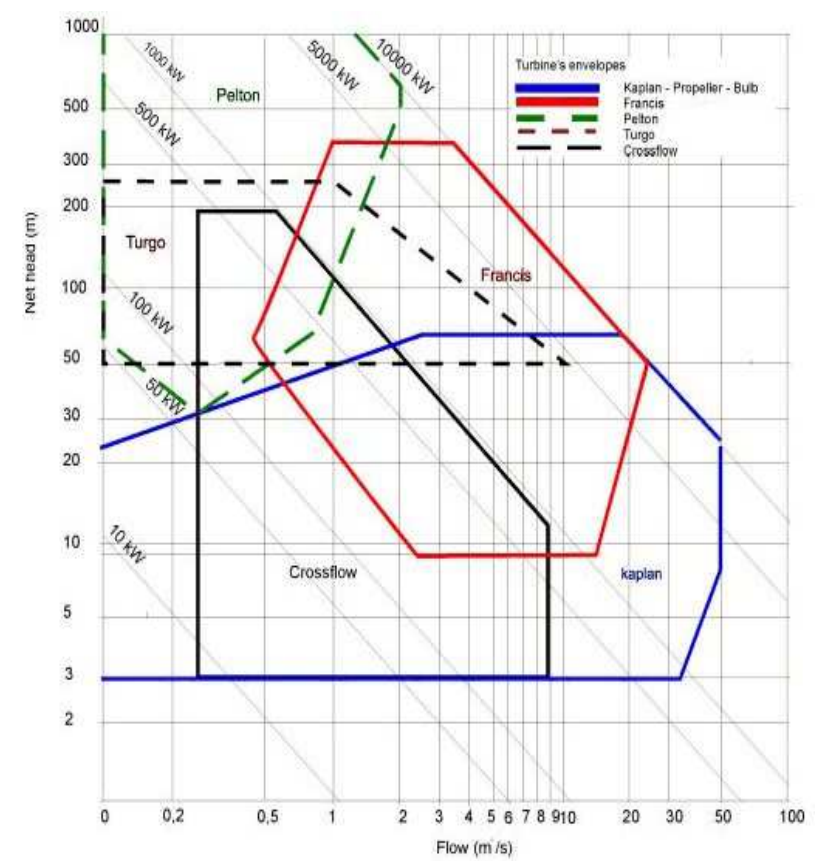

Figure 2. Turbine types and Range of Application [16]

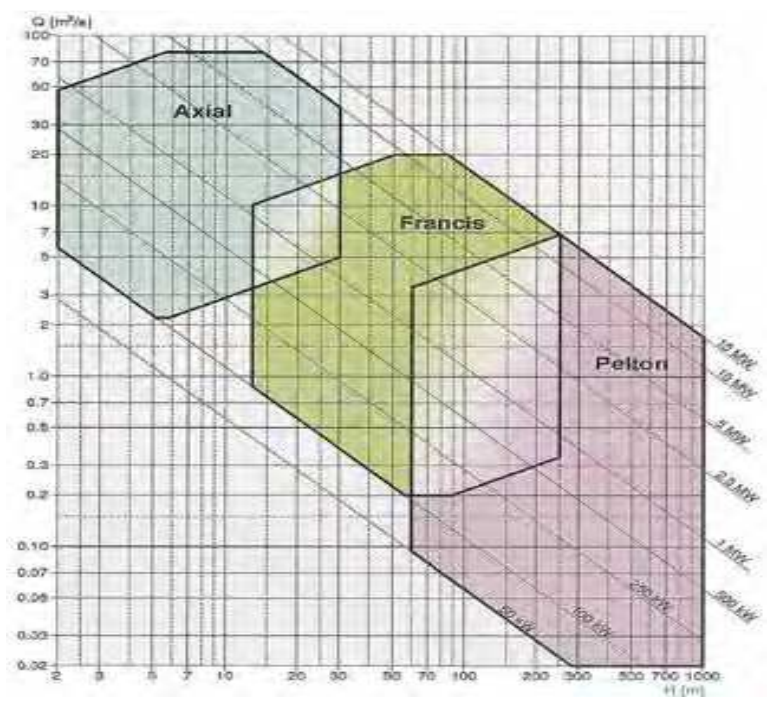

Figure 3. Turbine types and Range of Application [11]

\section{Discussion and Results}

\subsection{Case Study}

Watercourse:

- Opeki River

Water Regulatory Authority:

- Ogun Osun River Basin Development Authority (OORBDA)

Site Location:

- Abidogun Village,

- Iseyin Local Government Area, Oyo State, Nigeria

- Latitude 7०39’11’N, Longitude 3 57’42” E

- $294 \mathrm{~m}$ above sea level

Estimated Site Conditions:

- Gross Head $\left(\mathrm{H}_{\mathrm{g}}\right): 50 \mathrm{~m}$

- Maximum Tailwater Level $\left(\mathrm{h}_{\mathrm{w}}\right): 1.00 \mathrm{~m}$

- Residual Flow $\left(\mathrm{Q}_{\mathrm{r}}\right): 2.97 \mathrm{~m}^{3} / \mathrm{s}$

The net head $\left(H_{n}\right)$ was computed using (1)

- $\quad$ Net Head: $46.5 \mathrm{~m}$

Anticipated System Efficiencies and Losses (Typical values): [11]

- Generator Efficiency $\left(\eta_{\mathrm{g}}\right): 98 \%$

- Transformer Losses $\left(\zeta_{\mathrm{t}}\right): 1 \%$

- Conduit Head Percentage Losses $\left(\zeta_{\mathrm{h}}\right): 5 \%$

- Parasitic Electricity Losses $\left(\zeta_{\mathrm{p}}\right): 1 \%$

- Plant Availability (A): 98\%

\subsection{Power and Energy Assessment}

In the absence of long term records; short term records (seven years) of average daily flows from a gauging station at Abidogun village were acquired from Ogun - Osun River Basin Development Authority (OORBDA). These records were used to develop a flow duration curve for Opeki River. In order to ensure a residual flow $\left(\mathrm{Q}_{\mathrm{r}}\right)$ equal to $50 \%$ of minimum flow $\left(2.97 \mathrm{~m}^{3} / \mathrm{s}\right)$ was sustained annually as prescribed, (2) was applied to the primary flow duration curve. This effectively created a secondary flow duration 
curve comprising of flows available to the turbine for power generation. Primary and secondary flow duration curves for Opeki River are shown in Fig. 4. The average annual flow rate of Opeki River for the multi - year period represented by the FDC (less the residual flow) is $21.4 \mathrm{~m}^{3} / \mathrm{s}$ at $\mathrm{Q}_{40.5}$; indicating that the river exhibits significant variability annually.

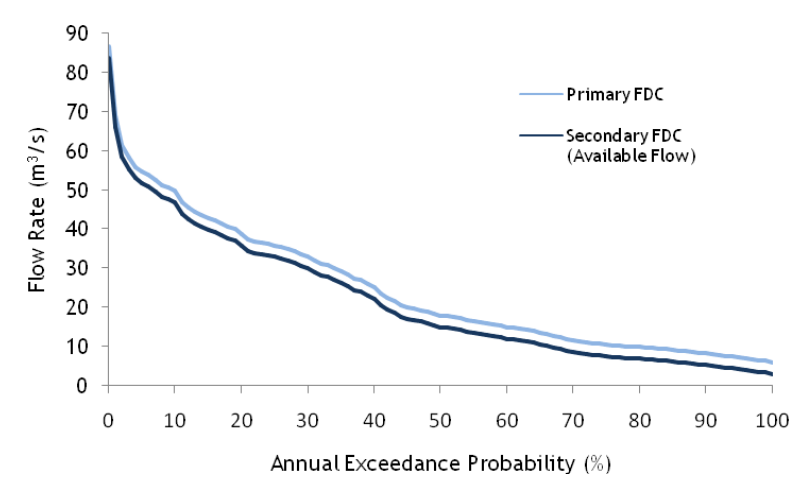

Figure 4. Primary and Secondary Flow Duration Curves for Opeki River

Taking the average annual flow $\left(\mathrm{Q}_{\mathrm{ave}}\right)$ as rated flow allowed an estimation of average potential power $\left(\mathrm{P}_{\mathrm{ave}}\right)$.

The small hydro plant rated output $\left(\mathrm{P}_{\mathrm{k}}\right)$ is obtained from (4) when; $\mathrm{Q}_{\mathrm{k}}=\mathrm{Q}_{\mathrm{j}}$. Therefore, when (4) was used with the appropriate turbine relative efficiencies derived from the turbine efficiency curves in Fig. 1 for Kaplan, Propeller, Francis, Crossflow, Pelton and Turgo turbines; plant rated output using $\mathrm{Q}_{\text {ave }}$ was calculated for each turbine type. Subsequently, by applying (7) to the exceedance probability associated with $\mathrm{Q}_{\text {ave }}$, the annual optimum operation period for the small hydro plant was estimated.

Again, when (4) was used with the appropriate turbine relative efficiencies along with available flows constituting the secondary FDC; the variation in turbine efficiency and change in plant output as available flows deviate from the plant's rated flow was computed for Kaplan, Propeller, Francis, Crossflow, Pelton and Turgo turbines. These results were plotted to form turbine efficiency curves and power duration curves. The turbine efficiency curve (TEC) shows the variation in turbine efficiency as available flows deviate from the rated flow of a turbine. The TEC in Fig 5 is plotted for a single Kaplan turbine proposed for the small hydro plant. The power duration curve (PDC) shows the drop in the small hydro plant's rated output as available flows falls below the plant's rated flow; hence the PDC describes the small hydro plant's ability to sustain output at reduced flows.
The PDC in Fig 6 is plotted for the proposed small hydro plant at average potential power with a single Kaplan turbine. Since a turbine will only accept flows equal to or less than its rated flow; when available flow exceeds the turbine's rated flow, the excess flow bypasses the turbine and the rated flow constitutes the flow used by the turbine.

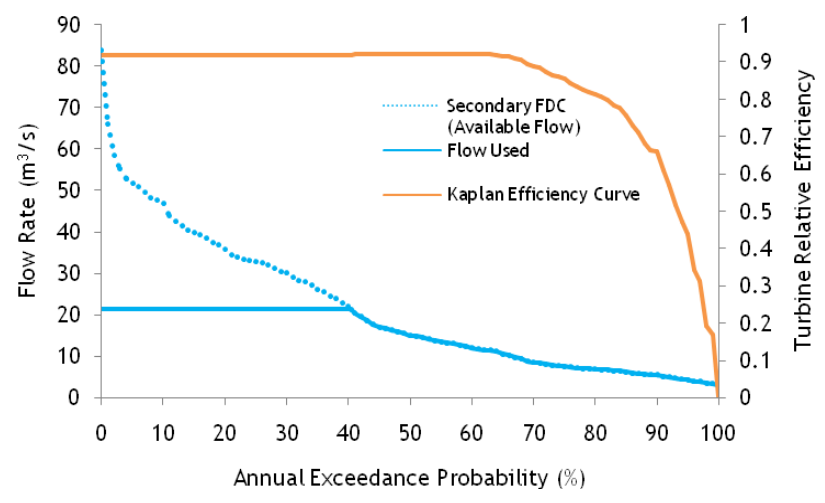

Figure 5. TEC for a single Kaplan turbine at average potential power

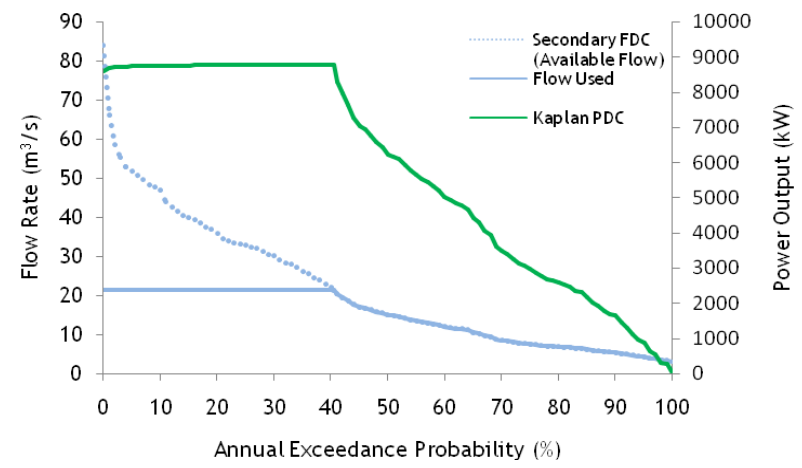

Figure 6. $P D C$ for the proposed small hydro plant at average potential power with a single Kaplan

With the power duration curve developed, (8) was used to estimate the annual maximum reduction in the small hydro plant's rated output. The annual energy produced by the small hydro plant was estimated by approximating the area of the region under the power duration curve using (10). Upon estimation of the plant's annual energy production, the small hydro plant annual capacity factor was calculated using (11). Results of the aforementioned assessment at average potential power for all turbines are summarized in Table 1.

Table 1. Assessment results at average potential power for all turbines

\begin{tabular}{llllll}
\hline Turbines Types & $\begin{array}{l}\text { Plant Rated } \\
\text { Output (kW) }\end{array}$ & $\begin{array}{l}\text { Annual Reduction in } \\
\text { Plant Output (kW) }\end{array}$ & $\begin{array}{l}\text { Annual Estimated Energy } \\
\text { Production (MWh) }\end{array}$ & $\begin{array}{l}\text { Optimum Capacity } \\
\text { Factor (\%) }\end{array}$ & $\begin{array}{l}\text { Annual Optimal Operation } \\
\text { Period (days) }\end{array}$ \\
\hline Kaplan & 8774 & 8774 & 50018 & 65.1 \\
Propeller & 8817 & 8817 & 41031 & 53.2 & 148 \\
Francis & 8463 & 8238 & 46607 & 62.9 \\
Crossflow & 7552 & 6878 & 42609 & 64.5 & 148 \\
1 Jet Pelton & 8741 & 7876 & 51320 & 67.1 & 148 \\
2 Jet Pelton & 8675 & 7792 & 50876 & 67.0 & 148 \\
1 Jet Turgo & 8454 & 7631 & 49643 & 67.0 \\
2 Jet Turgo & 8388 & 7547 & 49195 & 148 \\
\hline
\end{tabular}


Using the turbine application range chart in Fig. 2, Kaplan and Francis turbines were considered appropriate for the proposed small hydro plant at average potential power and the plant's expected optimum operation period is 148 days annually

With a single Kaplan turbine installed; the plant is estimated to have a rated output of $8.8 \mathrm{MW}$ and projected to produce $50018 \mathrm{MWh}$ of energy at $65.1 \%$ capacity factor as shown in Table 1. Consequently, there is an annual energy deficit of $23305 \mathrm{MWh}$. The Kaplan turbine is expected to attain an efficiency of $91.8 \%$ at rated flow which falls to $0 \%$ as a result of reduced flows during the dry season as shown in Fig 5. The proposed plant is not highly dependable as shown in Fig. 6; therefore, a standby capacity of 8.8 MW must be made available from a central grid or an independent source to compensate for the total loss of generation during the dry season.

Alternatively, with a single Francis turbine installed; the small hydro plant is estimated to have a rated output of 8.5 MW and projected to produce $46607 \mathrm{MWh}$ of energy at $62.9 \%$ capacity factor as shown in Table 1 . Consequently, there is an annual energy deficit of $25557 \mathrm{MWh}$. The Francis turbine is expected to attain an efficiency of $88.5 \%$ at rated flow which falls to $16.3 \%$ as a result of reduced flows during the dry season. The plant is not highly dependable; hence, a standby capacity of 8.3 MW must be made available from a central grid or an independent source to avoid severe power shortages during the dry season.

Power and energy estimates were made for a medium range of heads at average potential power. These results are shown in Table 2.

Table 2. Assessment Results at average potential power for different heads

\begin{tabular}{|c|c|c|c|c|c|}
\hline Suitable Turbine Type & Gross Head (m) & Net Head (m) & Plant Rated Output (kW) & $\begin{array}{l}\text { Annual Estimated Energy } \\
\text { Production (MWh) }\end{array}$ & Capacity Factor (\%) \\
\hline Kaplan & 10 & 8.5 & 1733 & 9507 & 62.7 \\
\hline Kaplan & 20 & 18 & 3523 & 19797 & 64.2 \\
\hline Kaplan & 30 & 27.5 & 5285 & 29934 & 64.7 \\
\hline Kaplan & 40 & 37 & 7035 & 40000 & 65.0 \\
\hline Kaplan & 50 & 46.5 & 8774 & 50018 & 65.1 \\
\hline Kaplan & 60 & 56 & 10510 & 60005 & 65.2 \\
\hline Francis & 70 & 65.5 & 11976 & 66907 & 63.8 \\
\hline Francis & 80 & 75 & 13726 & 77017 & 64.1 \\
\hline Francis & 90 & 84.5 & 15472 & 87106 & 64.3 \\
\hline
\end{tabular}

Taking the minimum annual flow $\left(\mathrm{Q}_{\min }\right)$ as rated flow allowed an estimation of minimum potential power $\left(\mathrm{P}_{\min }\right)$. The minimum annual flow rate of Opeki River obtained from the secondary FDC is $2.97 \mathrm{~m}^{3} / \mathrm{s}$ at $\mathrm{Q}_{100}$. A summary of assessment results for all turbines at minimum potential power is shown in Table 3.

Table 3. Assessment Results for at minimum potential power for all turbines

\begin{tabular}{llllll}
\hline Turbines Types & $\begin{array}{l}\text { Plant Rated Output Annual Reduction in } \\
(\mathbf{k W})\end{array}$ & $\begin{array}{l}\text { Annual Estimated Energy Capacity } \\
\text { Plant Output (kW) }\end{array}$ & $\begin{array}{l}\text { Annual Optimal } \\
\text { Production (MWh) }\end{array}$ & $\begin{array}{l}\text { Operation } \\
\text { Feriod (days) }\end{array}$ \\
\hline Kaplan & 1202 & 0 & 10316 & 97.8 & 365 \\
Propeller & 1208 & 0 & 10350 & 97.8 & 365 \\
Francis & 1160 & 0 & 9948 & 365 \\
Crossflow & 1050 & 0 & 9005 & 97.8 & 365 \\
1 Jet Pelton & 1168 & 0 & 10025 & 97.8 & 365 \\
2 Jet Pelton & 1160 & 0 & 9948 & 97.8 & 365 \\
1 Jet Turgo & 1128 & 0 & 9682 & 97.8 & 365 \\
2 Jet Turgo & 1120 & 0 & 9604 & 365 \\
\hline
\end{tabular}

Using the turbine application range chart in Fig. 2, Francis and Propeller turbines are considered appropriate for the proposed small hydro plant at minimum potential power. A Francis turbine is also considered suitable by the turbine application range chart in Fig. 3. At minimum potential power, rated flow is available throughout the year; therefore, the proposed plant expected annual optimum operation period is all 365 days annually.

With a single Francis turbine installed, the plant is estimated to have a rated output of $1.16 \mathrm{MW}$ and projected to produce $9948 \mathrm{MWh}$ of energy at $97.8 \%$ capacity factor as shown in Table 3. The Francis turbine is expected to maintain an efficiency of $87.3 \%$. Hence, the annual energy deficit of $214 \mathrm{MWh}$ is mainly due to the plant's $98 \%$ availability.

Alternatively, with a single Propeller turbine installed, the plant is expected to have a rated output of $1.2 \mathrm{MW}$ and projected to produce $10350 \mathrm{MWh}$ of energy at $97.8 \%$ capacity factor as shown in Table 3 . The Propeller turbine is expected to maintain an efficiency of $90.9 \%$. Hence, the 
annual energy deficit of $188 \mathrm{MWh}$ is mainly due to the plant's 98\% availability.

Power and energy estimates were made for a medium range of heads at minimum potential power. These results are shown in Table 4.

Table 4. Assessment Results at minimum potential power for different heads

\begin{tabular}{llllll}
\hline Suitable Turbine Type & Gross Head (m) & Net Head (m) & $\begin{array}{l}\text { Plant Rated Output } \\
(\mathbf{k W})\end{array}$ & $\begin{array}{l}\text { Annual Estimated Energy } \\
\text { Production (MWh) }\end{array}$ \\
\hline Francis & 10 & 8.5 & 160 & 1360 & \multicolumn{1}{c}{ Capacity Factor } \\
Francis & 20 & 18 & 420 & 3588 & 97.1 \\
Francis & 30 & 27.5 & 670 & 5733 & 7836 \\
Francis & 40 & 37 & 916 & 9948 & 97.5 \\
Francis & 50 & 46.5 & 1160 & 12042 & 97.8 \\
Francis & 60 & 56 & 1403 & 14120 \\
Francis & 70 & 65.5 & 1645 & 16189 \\
Francis & 75 & 1886 & 17305 \\
2 Jets Turgo & 90 & 84.5 & 2015 & 97.8 \\
\hline
\end{tabular}

\section{Conclusion}

Assessment results show that small hydro electric power generation from Opeki River can contribute in no small measure to improving electricity supply to nearby rural communities since the electrical energy demands of these communities are modest. Widespread development of small hydro power can contribute immensely to improving rural electricity access levels throughout Nigeria.

\section{References}

[1] IEA - International Energy Agency, "Access to Electricity," Report, Published by the International Energy Agency, Paris, France, 2012. http://www.iea.org/ weo/ electricity.asp

[2] Rosnes, O. and Vennemo, H., "Powering Up: Costing Power Infrastructure Spending Needs in Sub-Saharan Africa", African Infrastructure Country Diagnostic (AICD) Background Paper Number 5, World Bank, Washington, DC, USA, 2008

[3] Sambo, S. A., "Renewable Energy for Rural Development: The Nigerian Perspective," ISESCO Science and Technology Vision, Volume 1, ISESCO - Islamic Educational, Scientific and Cultural Organization, Rabat, Kingdom of Morocco, 2005. pp. $12-22$

[4] Kaunda, C., Kimambo, C. and Nielsen, T., "Potential of Small - Scale Hydropower for Electricity Generation in Sub Saharan Africa", ISRN Renewable Energy Journal, Volume 2012, Hindawi, New York, USA, 2012. pp. 1 - 15

[5] Ekpo, E. I., "Challenges of Hydro Power Development in Nigeria," Paper Number. 262, Hydro Vision 2008 Conference, $14^{\text {th }}-18^{\text {th }}$ July 2008, Sacramento, California, USA, 2008

[6] Zarma, H. I., "Hydro Power Resources in Nigeria: A Country Position Paper," $2^{\text {nd }}$ Hydro Power for Today Conference 2006, IC - SHP - International Centre on Small Hydro Power, Hangzhou, China, 2006.

[7] Boluwade, A., "Modeling Opeki River Flow for Sustainable Rural Development," in Proceedings of $29^{\text {th }}$ WEDC International Conference: Towards the Millennium Development Goals - Actions for Water and Environmental Sanitation, WEDC - Water Engineering and Development
Center, Abuja, Nigeria, September; 2003.pp. 1 - 3 http://www.lboro.ac.uk/resou rces /confer ences/29/alaba/pdf

[8] Basnyat, D., "Fundamentals of Small Hydro Power Technologies", Financing Cogeneration and Small - Hydro Projects in the Sugar and Tea Industry in East and Southern Africa Training, $19^{\text {th }}-23^{\text {rd }}$ June 2006, Nairobi, Kenya. ADB FINESSE Training Course on Renewable Energy and Energy Efficiency for Poverty Reduction; 2006, pp. 5 - 36

[9] BHA - British Hydropower Association, "A Guide to United Kingdom Mini - Hydro Developments", Version 1.2, London, United Kingdom, 2005. http://www.british-hydro.org/Useful20\%Information/A20\% Guide $20 \%$ to $20 \%$ UK20\%mini-hydro20\%develop ment $20 \%$ v3.pdf

[10] Natural Resources, Canada. "Small Hydro Project Analysis Chapter, RETScreen Engineering and Cases Textbook", Published by Natural Resources Canada. Ottawa, Canada, Catalogue No. M39 - 38/2003E - PDF, 2004.

[11] ESHA - European Small Hydropower Association, "Guide on How to Develop a Small Hydropower Plant", ESHA, Brussels, Belgium, 2004. http://www.esha.be/fileadmin/esha_files/documents/publicat ions/GUIDES/GUIDE_SHP/GUIDE_SHP_EN. pdf.

[12] Copestake, P. and Young, A., "How Much Water Can a River Give? Uncertainty and the Flow Duration Curve", British Hydrological Society (BHS), $10^{\text {th }}$ National Hydrology Symposium, Exeter, United Kingdom, 2002.

[13] Oregon State University, "Analysis Techniques: Flow Duration Tutorial", In Stream Flow Evaluations for Watershed Restoration Planning and Design,2005.http://www.water.oregonstate.edu/streamflow/i ndex.html

[14] Rajput, R. K., "A Textbook of Power Plant Engineering". Laxmi Publications Limited, New Delhi, India, 2008. pp. 22 28

[15] Kendall, A., "An Introduction to Numerical Analysis", $2^{\text {nd }}$ Edition, John Wiley and Sons Inc., New York, USA, 1989. pp. $37-45$

[16] Penche, C., "Layman's Guide on How to Develop a Small Hydro Site" $2^{\text {nd }}$ Edition, Directorate - General for Energy, Commission of European Communities, Brussels, Belgium, 1998. 